\title{
Basal cell adenoma mimicking adenoid cystic carcinoma on FNAC- A Case Report
}

\author{
Singh $A^{1}$, Sharma $R^{2}$, Nema $S^{3}$ \\ ${ }^{1}$ Dr Arjun Singh, Associate Professor, Department of Pathology, ${ }^{2}$ Dr Rashi Sharma, Tutor, Department of Pathology, ${ }^{3}$ Dr S \\ K Nema, Professor and Head, Department of Pathology. All are affiliated with Index Medical College Hospital \& Research \\ Center, Indore, Madhya Pradesh, India
}

Address for correspondence: Dr Arjun Singh, Email: dr_arjun12@yahoo.co.in

\begin{abstract}
A 40-year-old-female presented with a right parotid swelling. It was diagnosed as adenoid cystic carcinoma on FNAC. On histopathology final diagnosis of basal cell adenoma was made. Basal cell adenoma is a rare and benign basaloid neoplasm of the salivary gland. The other basaloid neoplasms are pleomorphic adenoma, basal cell adenocarcinoma, adenoid cystic carcinoma, metastatic basal cell carcinoma, metastatic squamous cell carcinoma and small cell carcinoma. Differentiating basaloid neoplasms on FNAC pose diagnostic difficulties. The goal is to discuss problems and pitfalls in FNAC diagnosis of basal cell adenoma and to emphasize on cautious approach while diagnosing basaloid neoplasm on cytology.
\end{abstract}

Keywords: Fine needle aspiration cytology, basal cell adenoma, adenoid cystic carcinoma, salivary gland.

\section{Introduction}

Among the various salivary gland neoplasm, basal cell adenoma is a rare benign epithelial tumor [1-3].

The majority of basal cell adenomas arise in the parotid gland [1-4].

The tumor is present more often in elderly females [2]. It presents as a distinct, mobile, painless swelling [3].

Cytological features consist of monomorphic basaloid cells and basement membrane like stromal component [4].

Diagnosing basal cell adenoma on fine needle aspiration cytology is a diagnostic challenge because it can mimic other basaloid tumors of the salivary gland.

These are benign as well as malignant tumors such as; cellular

pleomorphic adenoma, basal cell adenocarcinoma, adenoid cystic carcinoma, metastatic basal cell carcinoma, metastatic squamous carcinoma and small cell carcinoma $[3,5]$.

We report a case of basal cell adenoma in a 40 year-oldfemale, with right parotid swelling, misdiagnosed as adenoid cystic carcinoma on FNAC.

\section{Case report}

A 40-year-old-female presented with $5.0 \times 3.5 \mathrm{~cm}$, well defined, mobile swelling in right parotid region. Fineneedle aspiration cytology of the parotid swelling was done.

The aspirate yielded cellular smears with cells arranged in clusters around pink hyaline globules.

The nuclei were monomorphic with prominent nucleoli and scanty cytoplasm (Fig: 1).

Cytodiagnosis of adenoid cystic carcinoma was given. The differential diagnosis of pleomorphic adenoma and skin adnexal tumor (cylindroma) was also offered.

Excision biopsy was advised for confirmation of diagnosis.

Grossly, a well encapsulated grey-white tumor mass was noted (Fig: 2).

Histological examination revealed a well encapsulated tumor. The cells were arranged in nests with peripheral palisading (Fig: 3).

Individual cells were monomorphic and elongated with fibrillary material at places (Fig: 4). Final diagnosis of basal cell adenoma was made. 


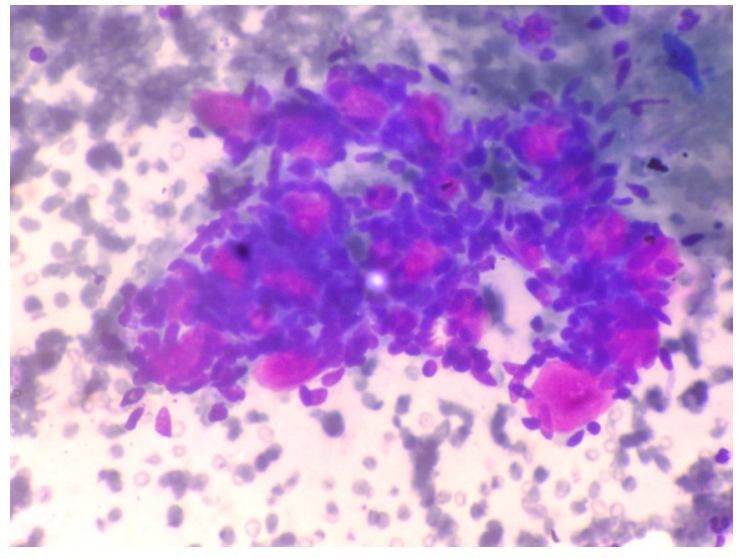

Fig 1: Fine needle aspiration cytology (FNAC) picture in May Grunwald Geimsa (MGG) staining at 100x Magnification

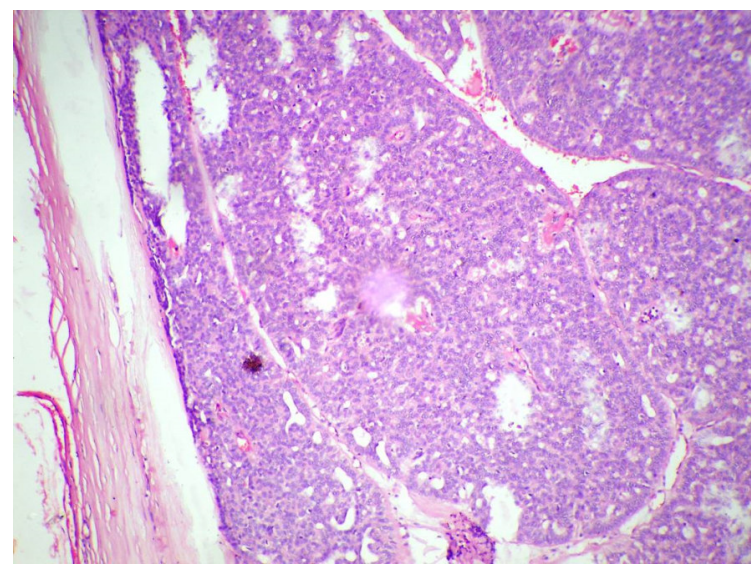

Fig 3: Histopathology in Hematoxyline \& Eosin (H \& E) Staining at $100 \mathrm{x}$ magnification

\section{Discussion}

FNAC is a useful tool in preoperative diagnosis of salivary gland tumors and helps in deciding further management $[6,7]$. Basaloid tumors are difficult to tackle on cytology $[5,7]$. In view of limitations of FNAC and to prevent pitfalls in cytological diagnosis certain guidelines can be followed along with careful approach $[6,8]$.

Cytological diagnosis not only can differentiate benign and malignant basaloid tumors but also prevents radical surgery in benign lesions.

Cytological smears of basal cell adenoma are cellular and characterized by uniform small cells with pale, basophilic cytoplasm and round to oval nuclei with granular chromatin arranged in clusters, cords and singles. A variable amount of eosinophilic, stromal basement membrane-like material is present, usually adjacent to the cell clusters.

Among the basaloid tumors basal cell adenoma can be misinterpreted as adenoid cystic carcinoma on FNAC [5,
Case Report

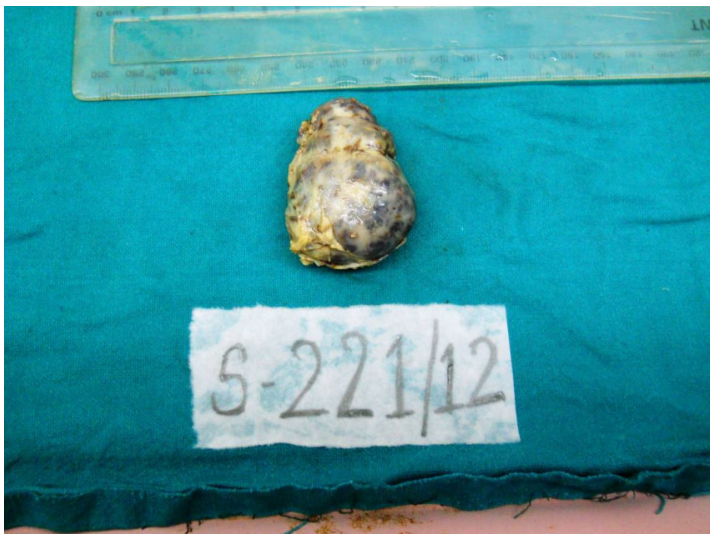

Fig 2: Gross photograph showing Well encapsulated, round to oval tumor mass

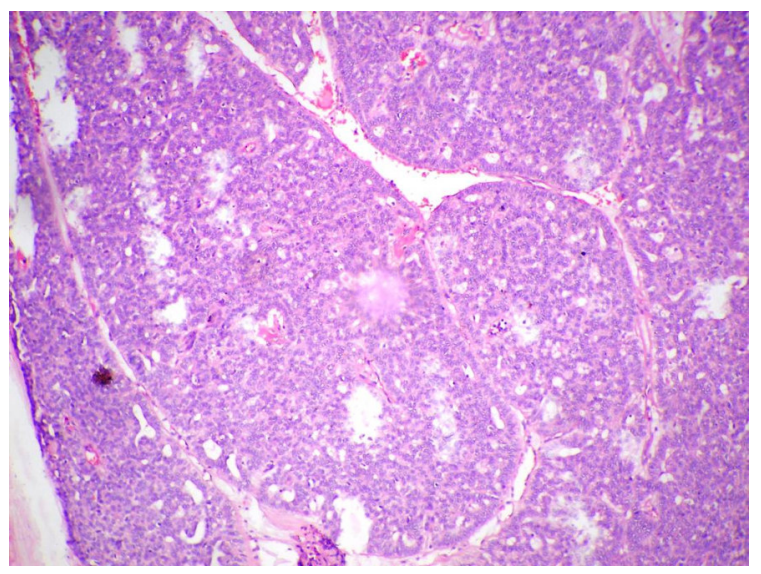

Fig 4: Histopathology in Hematoxyline \& Eosin (H \& E) staining at $100 \mathrm{x}$ magnification

$7,9]$. In this case report the reasons for misdiagnosis were age of the patient and hyaline globules around which

basaloid cells were arranged as in adenoid cystic carcinoma.

To differentiate basal cell adenoma and adenoid cystic carcinoma on FNAC, the characteristic features of cellstroma interface are useful $[8,9]$. In basal cell adenoma, the cells are intermingled with adjacent stroma, whereas in adenoid cystic carcinoma, the cells and stroma are sharply demarcated [8, 9]. Sometimes few vessels or spindle cells can be seen in stroma of basal cell adenoma, but the stromal globules of adenoid cystic carcinoma are acellular [9].

\section{Conclusion}

The management of basal cell adenoma is simple surgical excision. So, pre-operative FNAC diagnosis is very helpful and spares the patient from aggressive surgery. Since it is difficult to always give a definitive diagnosis of basal cell adenoma on cytology, it is wise to give 
differential diagnosis wherever necessary. However, careful approach and being aware of limitations of FNAC is helpful in making accurate diagnosis. The coordination between the clinician and the cytopathologist can improve the rate of accuracy and in doubtful cases confirmation should be done by histopathology examination.

Funding: Nil

Conflict of interest: Nil

Permission from IRB: Yes

\section{References}

1. Minicuccia EM, de Campos EB, Weber SA, Domingues MA, Ribeiro DA. Basal Cell Adenoma of the Upper Lip from Minor Salivary Gland Origin. Eur J Dent 2008; 2(3): 213-6.

2. Margaritescu C, Mercut V, Mogoanta L, florescu M, Simionescu C, Cionca L, Manea M. Salivary gland basal cell adenomas - immunohistochemical evaluation of four cases and review of the literature. Rom J Morphol Embryol 2005; 46(1): 29-40.

3. Gonzalez-Garcia R, Nam-Cha SH, Munoz-Guerra MF, Gamallo-Amat C. Basal cell adenoma of the parotid gland. Case report and review of the literature. Med Oral Patol Oral Cir Buccal. 2006; 11: e206-9.
Case Report

4. Jang M, Park D, Lee SR, Hahm CK, Kim Y, Kim Y, Park CK, Tae K, Park MH, Park YW. Basal Cell Adenoma in the Parotid Gland: CT and MR Findings. Am J Neuroradiol 2004; 25(4): 631-5.

5. Gupta N, Bal A, Gupta A, Rajwanshi A. Basal cell adenoma- A diagnostic dilemma on fine needle aspiration cytology. Diagn Cytopathol 2011; 39(12): 913-6.

6. Kotwal M, Gaikwad S, Patil R, Munshi M, Bobhate S. FNAC of Salivary Gland - A Useful Tool in Preoperative Diagnosis or a Cytopathogist's Riddle?. J Cytol 2007; 24 (2): $85-8$.

7. Anwar K, Iqbal J, Mohammad R, Khan M, Zada B. Differentiating Malignant from Benign Lesions- The Value of Preoperative Cytology in the Management of Parotid Neoplasms. Ann. Pak Ins. Med Sci 2012; 8(1): 704.

8. Hara H, Oyama T, Saku T. Fine needle aspiration cytology of basal cell adenoma of the salivary gland . Acta cytol 2007; 51(5): 685-91.

9. Stanley MW, Horwitz CA, Rollins SD, Powers CN, Bardales RH, Korourain S, Stern SJ. Basal cell (monomorphic) and minimally pleomorphic adenomas of the salivary glands.Distinction from the solid (anaplastic) type of adenoid cystic carcinoma in fine needle aspiration. Am J Clin Pathol 1996 ;106(1): 35-41.

\section{How to cite this article?}

Singh A, Sharma R, Nema SK. Basal cell adenoma mimicking adenoid cystic carcinoma on FNAC- A Case Report. Int J Med Res Rev 2014;2(2):166-168. doi:10.17511/ijmrr.2014.i02.19. 